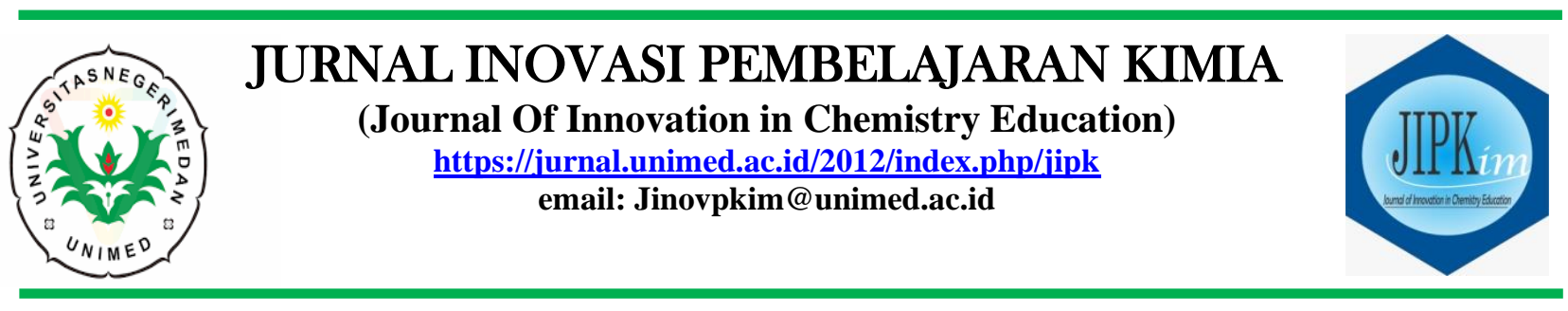

\title{
PENGEMBANGAN KIT PEMBELAJARAN DARI LIMBAH SEKAM PADI PADA MATERI BENTUK MOLEKUL KELAS X SMA
}

\author{
Adelia Yesya Putri Hasibuan ${ }^{\mathrm{a}, *}$, Iis Siti Jahro ${ }^{\mathrm{a}}$ \\ ${ }^{a}$ Program Studi Pendidikan Kimia, Universitas Negeri Medan, Medan
}

*Alamat Korespondensi: adheliahsb@gmail.com

\begin{abstract}
:
Learning media has a very important role because it can increase motivation, improve understanding and retention of learning. But the reality in school learning media is often overlooked for reasons of diffuclty finding the right media and limited time to make it yourself. To overcome the nothingness of learning media on molecular shape material, learning media from rice husk waste are developed. This study aims: (1)To know the feasibility of KIT learning media which used in learning activities. (2)To know student learning outcomes by using KIT learning media is higher than KKM. (3)To know student learning activities by using KIT learning media. This type of research is development of ADDIE research model carried out in class XI MIA 2 SMA Swasta Budisatrya Medan. The results of the research are: (1)KIT Learning on molecular shape material has been developed is feasible for use and is in accordance with Ministry of Education and Culture standards with a percentage of 96.87\%. (2)Student learning outcomes that use KIT learning media on molecular shape material are higher than KKM. (3) Student learning activities using KIT learning media on molecular shape materials reach the criteria of Good with an average value of 90 .
\end{abstract} Keywords:

KIT Learning, Molecular Shape, Rice Husk, Learning Outcomes, Learning Activities

\section{PENDAHULUAN}

Materi Bentuk Molekul merupakan materi pelajaran kimia di kelas $\mathrm{X}$ yang tercantum di dalam kurikulum 2013 yang memiliki karakteristik bersifat abstrak dan kompleks sehingga dianggap sulit oleh sebagian besar siswa sehingga minat siswa dalam mempelajari ilmu kimia rendah.

Pada materi Bentuk Molekul dibahas mengenai gambaran susunan atom-atom dalam suatu molekul berdasarkan susunan ruang pasangan elektron di sekitar atom pusat baik pasangan elektron bebas maupun yang berikatan. Materi ini bersifat abstrak sehingga siswa merasa kesulitan untuk memahami dan memeroleh gambaran mengenai bentuk molekul jika dipelajari hanya melalui membaca saja dan guru mengajarkannya tanpa bantuan media pembelajaran seperti molymod yang dapat membantu siswa untuk mengamati, merancang, menentukan dan memprediksi bentuk molekul suatu senyawa bukan hanya membayangkan saja (Hutahaean, 2019).

Molymod merupakan media pembelajaran yang tergolong mahal harganya di pasaran. Selain itu media pembelajaran molymod yang beredar di pasaran juga memiliki keterbasan jenis dan jumlah atom pusat sehingga tidak bisa digunakan untuk merangkai bentuk molekul dari senyawasenyawa anorganik dengan jumlah domain di sekitar atom pusat 5 dan 6 atau senyawa anorganik dengan atom pusat yang mengalami hibridisasi $\mathrm{dsp}^{3}$ dan $\mathrm{d}^{2} \mathrm{sp}^{3}$. Oleh karena itu berdasarkan kajian dari berbagai 
literatur maka peneliti melakukan pengembangan media pembelajaran pengganti molymod yang dapat digunakan untuk pembelajaran materi Bentuk Molekul.

Seperti halnya molymod maka pada media pembelajaran yang dikembangkan diantaranya terdapat bola-bola pejal sebagai atom-atom dengan jumlah sesuai dengan macam-macam senyawa yang bentuk molekulnya akan dipelajari. Untuk membuat bola-bola atom tersebut maka digunakan bahan dari limbah sekam padi karena (1) sekam padi mudah ditemukan, (2) bisa diambil secara gratis atau tidak perlu dibeli, (3) mudah dibentuk dan ringan sehingga mudah dibawa. Selain itu pemanfaatan sekam padi dapat membantu mengurangi keberadaan limbah pertanian yang mengganggu masyarakat.

Selain bola-bola pejal dari limbah sekam padi pada media yang dikembangkan juga terdapat limbah tusuk sate dan busur. Seperangkat media pembelajaran tersebut disimpan dalam suatu wadah dan dinamakan KIT. KIT merupakan seperangkat peralatan praktik yang bertujuan untuk meningkatkan prestasi belajar siswa dengan kondisi yang dinamis, kreatif, relevan, dengan kehidupan sehari-hari dan membantu guru dalam proses belajar mengajar sebagai media/alat bantu untuk mencapai tujuan pengajaran sesuai dengan kurikulum (Fauziyah, 2001). Penggunaan KIT pada proses pembelajaran dapat menciptakan suasana belajar yang menyenangkan sehingga dapat mendorong siswa aktif terlibat dalam proses pembelajaran dan dapat meningkatkan hasil belajar siswa (Harahap, 2018).

Berdasarkan hasil penelitian Epinur dkk., (2015), menunjukkan bahwa penggunaan KIT menarik minat belajar siswa, mempermudah konsep materi pembelajaran serta mempertinggi daya serap belajar siswa. Penelitian lain juga menunjukkan diperolehnya KIT yang praktis, menarik, layak diproduksi dan efektif digunakan dalam proses pembelajaran kimia (Zidny dkk., 2017).

\section{METODE}

Penelitian ini merupakan penelitian pengembangan (Development Research) yang dilakukan dengan tahapan ADDIE (Analysis, Design, DevelopmentImplementation, Evaluation) sebagaimana ditunjukkan pada gambar 1 .

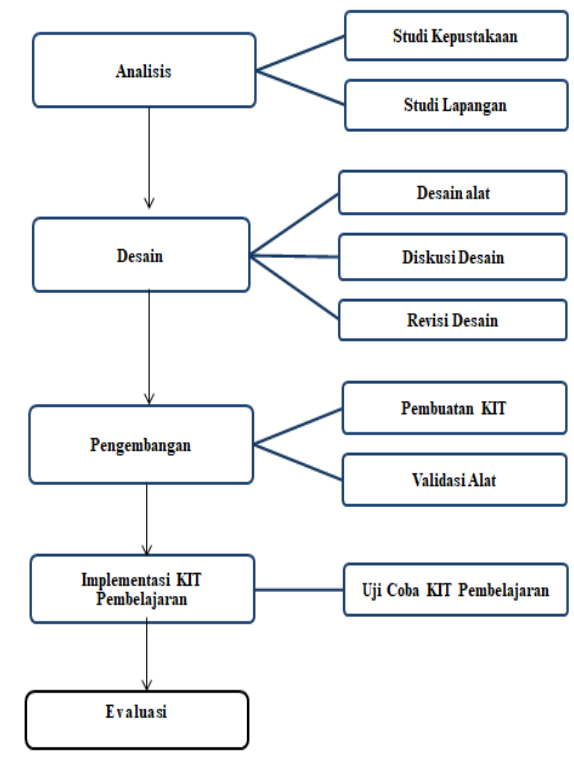

Gambar 1. Tahapan Prosedur Penelitian

Penelitian ini dilaksanakan di SMA Swasta Budisatrya Medan pada semester ganjil tahun ajaran 2019/2020 dengan rancangan One Group Pre-test - Post-test Design sebagaimana dirangkum pada tabel 1

Tabel 1. Rancangan Penelitian

\begin{tabular}{lccc}
\hline Kelompok & Pre-test & Perlakuan & Post-test \\
\hline Eksperimen & $\mathrm{T}_{1}$ & $\mathrm{X}$ & $\mathrm{T}_{2}$ \\
\hline
\end{tabular}

Keterangan:

$\mathrm{X}$ : Pembelajaran menggunakan KIT Bentuk molekul yang telah dikembangkan.

$\mathrm{T}_{1}$ : Pemberian tes awal (pre-test)

$\mathrm{T}_{2}$ : Pemberian tes akhir (post-test).

Sampel yang digunakan pada penelitian ini terdiri dari 1 dosen Kimia FMIPA Universitas Negeri Medan, 1 guru Kimia SMA Budisatrya Medan dan siswa kelas X MIA 2 SMA Budisatrya Medan yang berjumlah 32 orang.

Instrumen pengumpul data yang digunakan terdiri dari angket validasi tingkat kelayakan media pembelajaran, lembar observasi aktivitas siswa dan tes pilihan ganda dengan 5 option. 


\section{HASIL DAN PEMBAHASAN}

\section{Pengembangan KIT Pembelajaran}

Pengembangan KIT pembelajaran dari sekam padi dilakukan dengan prosedur sebagai berikut :

1) Membuat perekat atau lem dari campuran tepung kanji dan air.

2) Membuat adonan dari campuran sekam padi lem kanji.

3) Mencetak adonan dalam cetakan berbentuk bola. Ada 2 macam cetakan berbeda ukuran yang digunakan yaitu cetakan berdiameter 6 dan $4 \mathrm{~cm}$.

4) Menjemur adonan dalam cetakan di bawah sinar matahari hingga kering.

5) Mengeluarkan adonan dari cetakan sehingga diperoleh bola-bola dari sekam padi sebagai atom-atom. Bolabola berdiameter $6 \mathrm{~cm}$ digunakan sebagai atom pusat sedangkan bolabola berdiameter $4 \mathrm{~cm}$ sebagai atomatom yang terikat pada atom pusat.

6) Menghaluskan dan mewarnai bolabola dengan warna masing-masing atom sesuai teori seperti diantaranya warna hitam, putih dan kuning secara berturut-turut untuk atom karbon hidrogen dan belerang.

7) Menyiapkan komponen pendukung media lainnya seperti penghubung antar atom yaitu tusuk sate atau lidi dan busur untuk mengukur sudut serta kotak sebagai tempat penyimpanan sehingga diperoleh KIT sebagaimana ditunjukkan pada Gambar 2 .

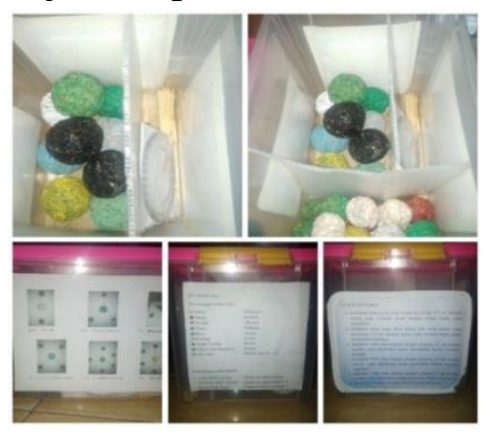

Gambar 2. KIT Pembelajaran

\section{Kelayakan KIT Pembelajaran}

Tingkat kelayakan KIT Pembelajaran ditentukan melalui validasi oleh 1 orang ahli media dan 1 orang ahli materi yaitu Dosen dan Guru. Hasil penilaian validator terhadap
KIT pembelajaran yang telah dikembangkan dirangkum pada tabel 2.

Tabel 2. Hasil Validasi KIT Pembelajaran

\begin{tabular}{|c|c|c|c|c|c|}
\hline \multirow{2}{*}{$\begin{array}{l}\text { Aspek } \\
\text { yang } \\
\text { dinilai }\end{array}$} & \multicolumn{3}{|c|}{$\begin{array}{c}\text { Penilaian Terhadap KIT } \\
\text { Pembelajaran }\end{array}$} & \multirow{2}{*}{$\%$} & \multirow{2}{*}{ Kriteria } \\
\hline & Dosen & Guru & $\begin{array}{c}\text { Rata- } \\
\text { rata }\end{array}$ & & \\
\hline $\begin{array}{l}\text { Keterkaitan } \\
\text { dengan } \\
\text { materi } \\
\text { pelajaran }\end{array}$ & 4,00 & 4,00 & 4,00 & 100 & $\begin{array}{l}\text { Sangat } \\
\text { Layak }\end{array}$ \\
\hline $\begin{array}{l}\text { Nilai } \\
\text { Pendidikan }\end{array}$ & 3,50 & 4,00 & 3,75 & 93,75 & $\begin{array}{l}\text { Sangat } \\
\text { Layak }\end{array}$ \\
\hline $\begin{array}{l}\text { Ketahanan } \\
\text { Alat }\end{array}$ & 4,00 & 4,00 & 4,00 & 100 & $\begin{array}{l}\text { Sangat } \\
\text { Layak }\end{array}$ \\
\hline $\begin{array}{l}\text { Keakuratan } \\
\text { Alat }\end{array}$ & 3,50 & 3,50 & 3,50 & 87,50 & $\begin{array}{l}\text { Sangat } \\
\text { Layak }\end{array}$ \\
\hline $\begin{array}{l}\text { Efesiensi } \\
\text { Alat }\end{array}$ & 4,00 & 4,00 & 4,00 & 100 & $\begin{array}{l}\text { Sangat } \\
\text { Layak }\end{array}$ \\
\hline $\begin{array}{l}\text { Keamanan } \\
\text { Bagi Siswa }\end{array}$ & 4,00 & 4,00 & 4,00 & 100 & $\begin{array}{l}\text { Sangat } \\
\text { Layak }\end{array}$ \\
\hline Estetika & 4,00 & 4,00 & 4,00 & 100 & $\begin{array}{l}\text { Sangat } \\
\text { Layak }\end{array}$ \\
\hline Kotak KIT & 4,00 & 3,50 & 3,75 & 93,75 & $\begin{array}{l}\text { Sangat } \\
\text { Layak }\end{array}$ \\
\hline $\begin{array}{r}\text { Kelas } \\
\mathrm{Ke}\end{array}$ & $\begin{array}{l}\text { kan Mec } \\
\text { luruhan }\end{array}$ & & 3,88 & 96,87 & $\begin{array}{l}\text { Sangat } \\
\text { Layak }\end{array}$ \\
\hline
\end{tabular}

Semua aspek yang merupakan kriteria kelayakan media berdasarkan Kemendikbud memperoleh persentase $96,87 \%$ sehingga KIT Pembelajaran pada materi bentuk molekul ini memenuhi kriteria Sangat Layak untuk digunakan sebagai media pembelajaran Kimia khususnya pada materi bentuk molekul.

Pada aspek keterkaitan dengan materi pelajaran, ketahanan, efesiensi, estetika dan keamanan alat bagi siswa mendapatkan nilai sempurna dengan persentase sebesar $100 \%$. Hal ini dimungkinkan karena KIT pembelajaran yang dikembangkan khusus untuk pembelajaran materi bentuk molekul sehingga keterkaitannya dengan materi sangat tinggi. Kemudian media bola-bola atom terbuat dari limbah sekam padi yang direkatkan dengan lem kanji yang kuat sehingga tidak mudah hancur, dengan demikian bisa digunakan secara berulangulang. Lalu KIT pembelajaran ini sangat efisiensi karena hanya dalam satu wadah sudah berisi semua yang diperlukan untuk menunjang praktik dalam pembelajaran. Selain itu, KIT ini sangat aman bagi siswa karena terbuat dari limbah sekam padi dan tidak terdapat zat kimia didalamnya. Aspek 
estetika bernilai sempurna dikarenakan alat peraga yang dibuat memiliki desain yang menarik dan atom-atom pembentuk senyawanya diberi warna berbeda pula.

\section{Hasil Belajar}

Peneliti terlebih dahulu memberikan pre-test kepada siswa. Selanjutnya siswa diberi materi bentuk molekul menggunakan KIT pembelajaran sebanyak 3 kali pertemuan (3 x 45 menit). Setelah perlakuan selesai siswa diberikan post-test.

Rerata hasil pre-test dan post-test disajikan pada gambar 3 yang menunjukkan adanya peningkatan hasil belajar dari pretest ke post-test sebesar 52\%. Hasil pre-test dengan rerata sebesar 26 menunjukkan tidak ada seorang siswa pun yang memeroleh nilai melebihi batas KKM (70). Hal ini menunjukkan siswa belum memiliki pengetahuan yang memadai materi bentuk molekul. Pada pre-test sebagian siswa dapat menjawab sebanyak 5 dari 20 soal yang diberikan dikarenakan soal-soal tersebut berhubungan dengan materi sebelumnya mengenai konfigurasi elektron, rumus molekul dan struktur Lewis. Pada hasil post-test diperoleh nilai rerata 78 dan menunjukkan ada 29 dari 32 siswa yang memperoleh nilai melebihi KKM. Menurut Akmalia (2018), KIT praktikum kimia efektif digunakan terhadap hasil belajar kognitif menunjukkan rata-rata hasil belajar siswa lebih besar dari nilai KKM yaitu 73.

Sebanyak 29 siswa yang mencapai nilai KKM dapat menjawab sebanyak 16 soal. Ada peningkatan soal yang dapat dijawab siswa antara pre-test dan post-test sebanyak 11 soal.

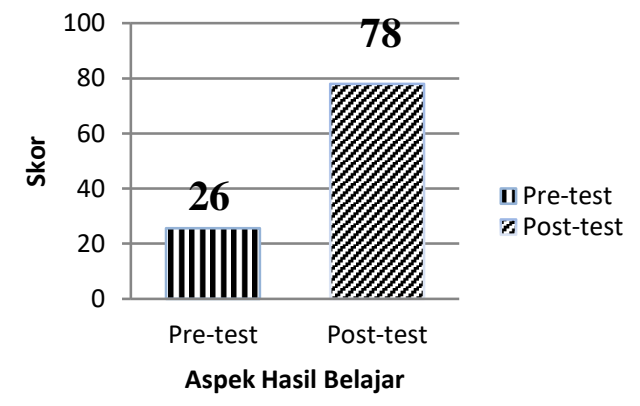

Gambar 3.Nilai Rata-Rata Pre-test dan Post-test
Pada umumnya soal yang bisa dijawab siswa pada post-test berkaitan dengan media KIT pembelajaran seperti soal mengenai penentuan bentuk molekul dari suatu senyawa, dengan adanya media maka dapat mempermudah siswa merancang geometri molekul dari senyawa tersebut sehingga siswa dapat mengetahui bentuk molekulnya.

Selanjutnya soal mengenai penentuan senyawa dengan gambar bentuk molekul yang disajikan. Penggunaan media berupa KIT pembelajaran dapat mempermudah siswa mempraktikkan geometri molekul dari senyawa-senyawa yang diberikan sehingga dapat menemukan geometri molekul yang sesuai dengan gambar dari soal tersebut.

Untuk membuktikan bahwa hasil belajar kimia siswa yang menggunakan KIT pembelajaran pada materi bentuk molekul lebih besar dari nilai KKM maka dilakukan uji hipotesis menggunakan uji t satu pihak dengan kriteria pengujian jika thitung $>t_{\text {tabel }}$ maka hipotesis alternative diterima dan $\mathrm{Ho}$ ditolak. Data hasil uji hipotesis menunjukkan nilai $t_{\text {hitung }}=5,973$ sedangkan pada $t_{\text {tabel }}=$ 1,695 , sehingga nilai $t_{\text {hitung }}$ lebih tinggi dari $t_{\text {tabel }}\left(t_{\text {hitung }}>t_{\text {tabel }}\right)$ maka $\mathrm{H}_{0}$ ditolak dan $\mathrm{Ha}$ diterima yang berarti bahwa hasil belajar kimia siswa yang dibelajarkan dengan menggunakan KIT pembelajaran pada materi bentuk molekul lebih tinggi dari nilai KKM yaitu 70 .

\section{Aktivitas Belajar}

Hasil penilaian observer pada angket terhadap aktivitas siswa (Yanti, 2018). disajikan pada tabel 3 yang menunjukkan aspek kerjasama mendapatkan nilai tertinggi sebesar 94\%. Hal ini dapat terlihat ketika dalam proses pembelajaran menggunakan KIT, setiap kelompok saling berdiskusi untuk memecahkan masalah yang diberikan dan bekerjasama dengan baik dalam merangkai bentuk molekul dari suatu senyawa yang diberikan. Sementara itu aspek ketelitian mendapatkan nilai 87 yang menunjukkan ada sebagian kelompok yang kurang begitu teliti dalam mengukur sudut dari senyawa yang 
diberikan. Pada aspek rasa ingin tahu, memiliki rata-rata nilai 90 yang terlihat dari antusias siswa-siswa tersebut saat menggunkan KIT pembelajaran. Siswa juga sangat disiplin dalam menyelesaikan LKPD yang diberikan sehingga mendapatkan nilai 89.

Tabel 3. Hasil penilaian aktivitas siswa

\begin{tabular}{|c|c|c|c|c|}
\hline \multirow{6}{*}{$\begin{array}{l}\text { Kelas } \\
\text { Eks. }\end{array}$} & \multirow{2}{*}{ Aspek } & \multicolumn{2}{|c|}{$\begin{array}{c}\text { Nilai } \\
\text { Aktivitas }\end{array}$} & \multirow{2}{*}{$\begin{array}{c}\text { Rata- } \\
\text { rata }\end{array}$} \\
\hline & & $\begin{array}{c}\text { Pert } \\
\text { I }\end{array}$ & $\begin{array}{c}\text { Pert. } \\
\text { II }\end{array}$ & \\
\hline & $\begin{array}{l}\text { Rasa Ingin } \\
\text { Tahu }\end{array}$ & 89 & 91 & 90 \\
\hline & Teliti & 87 & 88 & 87 \\
\hline & Kerjasama & 93 & 95 & 94 \\
\hline & Disiplin & 89 & 89 & 89 \\
\hline \multicolumn{4}{|c|}{ Rata-Rata } & 90 \\
\hline \multicolumn{4}{|c|}{ Kategori } & $\begin{array}{c}\text { Sangat } \\
\text { Aktif }\end{array}$ \\
\hline
\end{tabular}

Berdasarkan hasil penilaian observer, dapat diketahui bahwa aktivitas belajar siswa yang dibelajarkan dengan KIT pembelajaran mencapai kriteria Sangat Aktif dengan ratarata nilai akhir $90 \%$.

\section{KESIMPULAN}

Berdasarkan hasil penelitian dan analisis yang telah dilakukan, diperoleh beberapa kesimpulan sebagai berikut:

1. KIT Pembelajaran pada materi bentuk molekul layak untuk digunakan dan sudah sesuai dengan standar Kemendikbud

2. Hasil belajar siswa yang menggunakan media pembelajaran KIT pada materi bentuk molekul lebih tinggi dari KKM.

3. Aktivitas belajar siswa dengan menggunakan media pembelajaran KIT pada materi bentuk molekul mencapai kriteria Sangat Aktif.

\section{DAFTAR PUSTAKA}

Akmalia, N. (2018). Inovasi Penuntun Dan KIT Praktikum Kimia SMA Kelas XI Semester II Terintegrasi Model Inkuiri Terbimbing Merujuk 2013 (Doctoral dissertation, UNIMED).

Epinur, dkk., (2015). Pengembangan KIT Praktikum dan Lembar Kegiatan
Peserta Didik (LKPD) Materi Laju Reaksi untuk Siswa SMA, Prosiding SEMIRATA 2015 bidang MIPA BKSPTN Barat.

Fauziyah, I., (2001). Studi Eksplorasi Pemanfaatan Alat Peraga KIT Bentuk molekul SD Sebagai Sumber Belajar Dalam Pembelajaran IPA Oleh GuruGuru SD Se-Kecamatan Batur Kabupaten Banjar Negara Tahun Ajaran 2000/2001, Skripsi, Jurusan Fisika FMIPA Unnes, Semarang.

Harahap, J., (2018). Pengembangan Penuntun dan KIT Praktikum Kimia Inovatif Berbasis PBL (Problem Based Learning) sesuai Kurikulum 2013 Kelas XII SMA/MA Semester Genap (Doctoral Dissertation, UNIMED).

Hutahaean, F. N., (2019). Pengembangan Penuntun dan KIT Praktikum IPA Terpadu Terintegrasi Model Inkuiri Terbimbing Berbasis Keterampilan Proses Sains untuk Kelas VII Semester I(Doctoral Dissertation, UNIMED).

Yanti, F., (2018). Pengembangan Penuntun dan KIT Praktikum Kimia Inovatif Berbasis PBL (Problem Based Learning) sesuai Kurikulum 2013 Untuk SMA/MA Kelas XI Semester Genap (Master thesis, UNIMED).

Zidny, R., Dirayati, Y., Intan, A., \& Nur, I. E., (2017). Uji Kelayakan KIT Praktikum Pengujian Kepolaran Senyawa dari Material Sederhana, Jurnal Riset Pendidikan Kimia, 7(1): 52-53. 